\title{
PRODUKSI DAN KANDUNGAN HARA SERASAH PADA HUTAN RAKYAT NGLANGGERAN, GUNUNG KIDUL, D.I. YOGYAKARTA
}

\author{
(Production and Nutrient Content of Litter in Nglanggeran Community Forest, \\ Gunung Kidul, D.I. Yogyakarta) \\ Andi Gustiani Salim ${ }^{1}$ dan/and Budiadi $^{2}$ \\ ${ }^{1}$ Pusat Litbang Konservasi dan Rehabilitasi \\ Jl. Gunung Batu no.5 Po Box 165 Bogor \\ Telp.0251-8633234, Faks 0251-8638111 Email: a_gustiani@yahoo.com \\ ${ }^{2}$ Fakultas Kehutanan Universitas Gadjah Mada \\ Jl. Agro No. 1 Bulaksumur, Yogyakarta \\ Telp. 0274-548815, Faks. 0274-548815
}

Naskah masuk : 24 Juni 2013; Naskah diterima : 15 April 2014

\begin{abstract}
The pattern of private forest management in the Nglanggeran village, Gunung Kidul are forest, home garden and dry field garden. This research aims to determine the litter production, composition and nutrient content in each pattern. The results revealed that the highest litter production was on the HR 3 (6.05 ton/ha/6 months) followed by HR 2 (5.64 ton/ha/6 months) and HR 1 (4.61 ton/ha/6 months). Leaf litter was the largest composition of the forest litter. Decomposition of the litter contribute nutrients to the soil up to $80.56 \mathrm{~kg} / \mathrm{ha}$ of $\mathrm{N}, 3.50 \mathrm{~kg} / \mathrm{ha}$ of $P$, and 14.73 $\mathrm{kg} / \mathrm{ha}$ of K in the dry field garden; $69.58 \mathrm{~kg} / \mathrm{ha}$ of $\mathrm{N} ; 3.38 \mathrm{~kg} / \mathrm{ha}$ of $P$; dan $14.28 \mathrm{~kg} / \mathrm{ha}$ of K in the home garden and the lowest is forest (53.15 kg/ha of N; $1.95 \mathrm{~kg} / \mathrm{ha}$ of $P$ and $7.18 \mathrm{~kg} / \mathrm{ha}$ of $\mathrm{K})$. Nutrient from litters are not yet enough to fulfill the nutrient requirement of the crops and trees.
\end{abstract}

Keywords: Community forest, agroforestry, litterproduction, nutrient

\begin{abstract}
ABSTRAK
Bentuk pengelolaan khas hutan rakyat di Desa Nglanggeran, Kecamatan Patuk, Kabupaten Gunung Kidul, ada tiga macam, yaitu alas (hutan), pekarangan, dan tegalan. Penelitian ini bertujuan untuk mengetahui produksi dan jenis serasah dominan serta menganalisis kandungan nutrisinya sehingga dapat menjadi bahan pertimbangan dalam pemilihan jenis yang dapat menambah unsur hara pada tanah. Hasil penelitian menunjukkan urutan produksi serasah adalah dari HR3 (6,05 ton/ha/6bln), HR2 (5,64 ton/ha/6 bln) dan HR1 (4,61 ton/ha/6 bln). Berat serasah daun sebesar 5,150 ton/ha $(77,07 \%)$ di HR3, 5,218 ton/ha $(76,22 \%)$ di HR2 dan 3,816 ton/ha $(66,96 \%)$ di HR1. Produksi serasah tersebut jika terdekomposisi sempurna selama 6 bulan akan menambah unsur hara ke tanah HR3 sebesar 80,56 $\mathrm{kg} / \mathrm{haN} ; 3,50 \mathrm{~kg} / \mathrm{ha} \mathrm{P}$; dan 14,73 kg/ha K, HR2 (69,58 kg/ha N; 3,38 kg/ha P; dan 14,28 kg/ha K), dan paling rendah pada HR1 $(53,15 \mathrm{~kg} / \mathrm{ha} \mathrm{N} ; 1,95 \mathrm{~kg} / \mathrm{ha}$ P dan 7,18 kg/ha K). Untuk memenuhi kebutuhan hara baik tanaman pertanian maupun tanaman hutan (pohon) kandungan hara serasah ini belum mencukupi sehingga perlu dikombinsikan dengan jenis lain seperti legum.
\end{abstract}

Kata kunci : Hutan rakyat, agroforestri, produksi serasah, unsur hara

\section{PENDAhULUAN}

Pencampuran tanaman dalam suatu sistem penanaman sangat mempengaruhi siklus unsur hara yang terjadi dalam suatu ekosistem, seperti yang terjadi pada hutan rakyat. Pengelolaan hutan rakyat biasanya mengkombinasikan beberapa jenis yang dianggap menguntungkan antara tanaman semusim dan tanaman tahunan maupun sesama tanaman tahunan. Pohon merupakan penghasil serasah yang cukup besar dan berperan penting dalam menjaga dan mengembalikan kesuburan tanah terutama dalam sistem penanaman agroforestri. Menurut Joe et al. (2010), sebagian besar serasah terdiri bahan tanaman yang sudah mati dan terdapat pada permukaan tanah, dan secara ekologi lapisan serasah merupakan komponen utama ekosistem daratan yang menjadi sumber 
bahan organik tanah dan sebagai tempat prosesproses biologi tanah seperti dekomposisi dan dimulainya siklus hara.

Jika dibandingkan dengan sistem penanaman tunggal (monocropping), pohon dalam sistem agroforestri dapat meningkatkan kandungan bahan organik tanah dengan menambahkan jumlah input bahan organik diatas maupun di bawah permukaan tanah (Jose, 2009; Nair et al., 2009). Jatuhan dan dekomposisi serasah dari pohon dalam sistem agroforestri dipertimbangkan sebagai faktor penting yang berkontribusi terhadap kualitas tanah. Unsur hara yang kembali melalui serasah berperan penting dalam menjaga kesuburan tanah dan produktivitas primer ekosistem hutan (Gnankambary, 2008). Akumulasi serasah akan menyediakan habitat dan sumber makanan bagi mikro dan makro invertebrata yang merupakan dasar penting dalam rantai makanan (Sangha, 2006). Menurut Tripathi et al. (2009), evaluasi tentang produksi serasah sangat penting dalam memahami siklus hara, pertumbuhan hutan, dan interaksi dengan faktor lingkungan dalam ekosistem hutan.

Desa Nglanggeran merupakan desa yang memiliki hutan rakyat yang cukup berkembang. Masyarakat cukup tertarik menanami lahannya dengan tanaman kayu-kayuan. Hutan rakyat dibuat pada lahan alas (hutan), pekarangan dan tegalan. Bentuk pengelolaan tersebut merupakan tahapan perubahan model pengelolaan lahan yang mengikuti perkembangan penutupan lahan oleh tajuk tanaman tahunan (pohon). Menurut Dirjen RLPS (2006), hutan rakyat merupakan hutan yang dimiliki oleh rakyat dengan luas minimal 0,25 ha dengan penutupan tajuk tanaman kayu-kayuan dan/atau jenis tanaman lainnya lebih dari $50 \%$ dan/atau pada tanaman tahun pertama dengan tanaman sebanyak minimal 500 tanaman per hektar. Pekarangan, menurut Sunu dan Wartoyo (2006) memberikan kesan pada yang melihatnya sebagai hutan rimba yang produktif (agroforestri) atau sebagai kebun yang terlantar karena pekarangan tersebut ditumbuhi oleh bermacam-macam tanaman. Pekarangan berada pada lahan sekitar permukiman yang merupakan kombinasi antara tanaman semusim dan tanaman tahunan. Tegalan menurut Jamadi (2009) adalah suatu daerah dengan lahan kering yang bergantung pada pengairan air hujan, ditanami tanaman semusim atau tahunan dan terpisah dari lingkungan dalam sekitar rumah. Tetapi karena tajuk tanaman sudah sangat rapat, pada beberapa lahan tegalan tidak lagi dilakukan tumpangsari tanaman semusim.
Jenis-jenis yang banyak ditanam masyarakat di Desa Nglanggeran antara lain mahoni, akasia, sonokeling, sengon dan tanaman pencampur lainnya. Pada lahan pekarangan dan tegalan, masyarakat melakukan penanaman dengan mencampur berbagai jenis tanaman sedangkan pada hutan umumnya didominasi akasia yang dicampur dengan sebagian kecil sonokeling.

Pencampuran jenis tanaman ini mempengaruhi siklus bahan organik dan hara di dalam hutan rakyat. Siklus hara tersebut mempengaruhi tingkat kesuburan tanah, karena input unsur hara yang disumbangkan tanaman sangat dipengaruhi oleh kualitas serasah yang dihasilkan. Produksi serasah dan dekomposisi serasah berperan besar dalam dinamisasi dan siklus nutrisi pada ekosistem hutan (Triadiati et al.,2011).

Meskipun selama ini telah banyak penelitian mengenai produksi serasah di berbagai tipe ekosistem antara lain produksi serasah pada: serasah hutan mangrove Blanakan di Subang oleh Siarudin dan Rahman (2010); serasah hutan dataran rendah TN Gunung Gede Pangrango oleh Rahajoe dan Alhamd (2013); hutan hujan dan agroforestri di Amazon Tengah oleh Martius et al. (2004); hutan tropis di China oleh Tanget et al. (2010); dan pada hutan alam dan agroforestri kakao di Sulawesi Tengah oleh Tridiati et al. (2011), namun informasi mengenai produksi serasah dan kandungan haranya pada hutan rakyat berbentuk hutan (alas), pekarangan dan tegalan masih sangat terbatas. Untuk itu perlu diketahui kapasitas produksi serasah yang dihasilkan dari ketiga bentuk hutan rakyat tersebut pada periode tertentu serta konsentrasi kandungan hara ( $\mathrm{N}, \mathrm{P}$ dan $\mathrm{K})$, sehingga dapat diketahui peranannya dalam siklus hara dalam ekosistem. Hasil penelitian diharapkan dapat digunakan untuk memperbaiki rekomendasi mengenai pengaturan komposisi penyusun hutan rakyat yang dapat meningkatkan produktivitas.

\section{METODOLOGI}

\section{A. Tempat dan Waktu Penelitian}

Lokasi penelitian secara administratif terletak di Desa Nglanggeran, Kecamatan Patuk, Kabupaten Gunung Kidul, Propinsi D.I. Yogyakarta. Kecamatan Patuk secara geografis terletak pada $110^{\circ} 21^{\prime}-111^{\circ} 50^{\prime}$ BT dan $7^{\circ} 46^{\prime}-$ $8^{\circ} 09^{\prime} \mathrm{LS}$ (Anonim, 2005). Desa tersebut terletak pada ketinggian $700 \mathrm{~m}$ dpl dengan topografi wilayah yang umumnya berbukit dan bergu- 
nung. Rata-rata curah hujan tahunan pada lokasi penelitian sebesar $1.859 \mathrm{~mm}$ dan berdasarkan tipe iklim Schmidt dan Ferguson (1951), termasuk dalam tipe iklim D (sedang) (BPP Patuk, 2010). Jenis tanah pada lokasi penelitian adalah Alfisol.

Penelitian dilaksanakan selama enam bulan yaitu Bulan Januari sampai dengan Juni 2011, untuk merepresentasikan musim hujan (3 bulan) dan peralihan ke musim kemarau (3 bulan).

\section{B. Bahan dan Alat Penelitian}

Penelitian menggunakan bahan berupa serasah tegakan hutan rakyat, tali rafia, tali nilon, kantong plastik, dan bambu. Alat-alat yang digunakan yaitu littertrap terbuat dari nilon berukuran $50 \mathrm{~cm}$ x $50 \mathrm{~cm}$, timbangan analitik, amplop, stapler, gunting, oven, pengukur kelembaban dan suhu tanah aktual, pita ukur, meteran dan alat tulis.

\section{Metode Penelitian}

Penelitian dilakukan pada lahan hutan rakyat yang berbeda pengelolaan yaitu: (1) Hutan/Alas (HR1) didominasi jenis akasia $(53,12 \%)$, sonokeling (32,59\%), dan lain-lain (14,29\%); (2) Pekarangan (HR2) didominasi jenis mahoni $(63,04 \%)$, sonokeling $(26,81 \%)$ dan lain-lain (10,15\%); (3) Tegalan (HR3) didominasi oleh mahoni $(68,58 \%)$, sonokeling $(11,50 \%)$, dan lain-lain $(19,92 \%)$.

Penelitian dilakukan dengan membuat plot berukuran $20 \mathrm{~m} \times 20 \mathrm{~m}$ pada HR1, HR2 dan HR3. Masing-masing dilakukan ulangan sebanyak tiga kali, sehingga keseluruhan ada sembilan plot. Tahapan pelaksanaan penelitian adalah sebagai berikut:

1. Produksi serasah diukur dengan menggunakan littertrap yang dibuat dari kasa nilon berukuran $1 \mathrm{~mm}$ x $1 \mathrm{~mm}$, berukuran $50 \mathrm{~cm} \mathrm{x}$ $50 \mathrm{~cm}$ sebanyak 5 (lima) buah pada masingmasing plot, dengan 3 kali ulangan sehingga keseluruhan berjumlah 45 littertrap. Littertrap dipasang pada tempat-tempat yang dianggap mewakili dan dipasang setinggi 50 $\mathrm{cm}$ di atas permukaan tanah untuk menghindari kontaminasi dengan tanah dan binatang lainnya (Anderson dan Ingram, 1993).

2. Pengambilan sampel serasah dilakukan dengan interval dua minggu. Sampel dipisah berdasarkan jenisnya dan bagian-bagian tanaman (ranting, daun dan bunga/buah). Kemudi- an serasah dikeringkan dengan oven pada suhu $70^{\circ} \mathrm{C}$ selama 72 jam dan ditimbang berat keringnya.

3. Analisis kandungan hara serasah dilakukan setiap 2 (dua) bulan sekali dengan menganalisis kandungan N, P dan K serasah. Metode yang digunakan untuk menganalisis $\mathrm{N}$-total adalah dengan metode Kjeldahl dan untuk menganalisis P-total dan K-total menggunakan metode pembakaran basah (Wet Combustion) $\mathrm{H}_{2} \mathrm{SO}_{4}$ dan $\mathrm{H}_{2} \mathrm{O}_{2}$.

4. Pengamatan dan pengambilan sampel dilakukan selama 24 minggu pada masing-masing plot, dan ditabulasi berdasarkan jenis dan bagian, kemudian dianalisis secara deskriptif. Kandungan serasah masing-masing plot dianalisis secara grafis dan deskriptif.

\section{HASIL DAN PEMBAHASAN}

Menurut Indriyanto (2009) serasah yang dihasilkan oleh hutan mempunyai jumlah dan komposisi berbeda berdasarkan struktur dan keanekaragaman jenis tanaman penyusun.

Produksi serasah selama 6 bulan tertinggi pada plot tegalan sebesar 6,05 ton/ha, kemudian pekarangan dan hutan masing-masing 5,64 dan 4,61 ton/ha (Gambar 1).

Perbedaan produksi serasah ini disebabkan oleh struktur dan komposisi tegakan yang berbeda (Lampiran 1) dan faktor biofisik lingkungan yang mendukung pertumbuhan tanaman juga berbeda. Rendahnya produksi serasah pada hutan disebabkan oleh pertumbuhan tanaman yang tidak optimal karena kurang atau bahkan tidak adanya kegiatan pemeliharaan tanaman. Petani tidak melakukan kegiatan pemeliharaan pada lahan hutan rakyat berupa hutan (alas), permudaan yang terjadipun secara alami sehingga sangat bergantung pada kondisi lingkungan. Hal ini menyebabkan tanaman akasia dan sonokeling sebagai jenis yang dominan harus bersaing dengan semak belukar sehingga hanya tanaman yang mampu beradaptasi dengan lingkungan yang mampu tumbuh.

Fluktuasi produksi serasah setiap bulannya pada ketiga plot berbeda-beda (Gambar 1). Pada HR2 dan HR3 produksi serasah hampir sama, menurun sampai Bulan Maret (0,72 ton/ha dan 0,49 ton/ha) dan produksi meningkat pada Bulan April yaitu 0,82 ton/ha dan 1,16 ton/ha (menjelang musim kemarau). Hal ini kemungkinan di- 


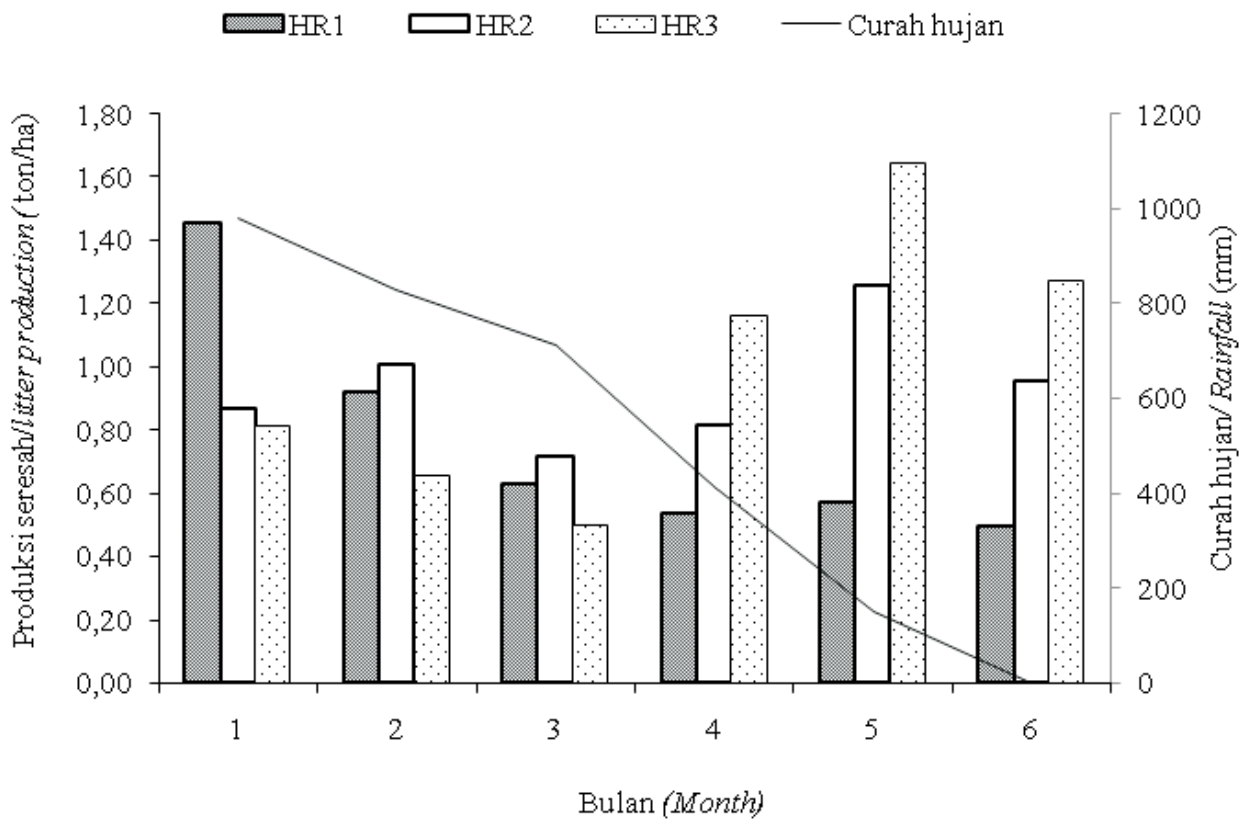

Gambar(Figure) 1. Produksi serasah (ton/ha) selama 6 bulan (Januari-Juni 2011) pada HR1, HR2 dan HR3 di Desa Nglanggeran, Gunung Kidul (Average litter production in six months observations (January-June 2011 (ton/ha) on HR1, HR2 and Hr3 in Nglanggeran Village, Gunung Kidul)

sebabkan oleh beberapa hal antara lain peralihan dari musim hujan ke musim kemarau dimana kerusakan tanaman karena kecepatan angin (angin kencang) dan hujan deras yang menyebabkan daun-daun berjatuhan mulai menurun. Selain itu, perbedaan fluktuasi jatuhan serasah juga dipengaruhi oleh jenis penyusun tegakan. Masingmasing jenis memiliki perbedaan kemampuan dalam beradaptasi terhadap lingkungan, antara lain terhadap stress air. Menurut Bray dan Gorham (1964) dalam Murovhi (2012), stress air, terpaan sinar matahari, umur tanaman dan kesuburan tanah dapat menginisiasi pembentukan abscissic acid yang akan menstimulasi penuaan pada daun maupun bagian tanaman lainnya.

Lain halnya pada HR1 yang didominasi $A$. mangium, produksi serasah cenderung menurun meskipun mulai awal kemarau kemungkinan karena penutupan tajuk tidak terlalu rapat sehingga produksi seresah juga tidak terlalu banyak. Pada HR1, permudaan terjadi secara alami sehingga regenerasi tanaman bergantung pada kemampuan semai untuk beradaptasi dengan kondisi lingkungan dan tidak dilakukan kegitan pemeliharaan menyebabkan tumbuhan bawah didominasi semak belukar, tanaman tumbuh tidak optimal, sehingga penutupan tajuk tidak terlalu rapat.

Hasil produksi serasah hutan pada penelitian ini lebih rendah jika dibandingkan dengan hasil penelitian Widyastuti et al.(1998) mulai Bulan Desember 1995 - Mei 1996, produksi serasah pada tegakan akasia di Hutan Pendidikan Wanagama I sebesar $699,65 \mathrm{~g} / \mathrm{m}^{2}$ atau setara dengan 6,99 ton/ha yang artinya lebih besar $34,05 \%$ dari produksi serasah hutan rakyat. Menurut Widyastuti et al. (1998), perbedaan berat serasah mangium per 4 (empat) minggu dipengaruhi oleh cuaca/ iklim pada periode waktu tersebut. Hal ini disebabkan oleh faktor lingkungan antara lain angin kencang menyebabkan produksi serasah akan meningkat. Penelitian ini dilakukan selama musim hujan dan awal musim kemarau, diperkirakan pada musim kemarau produksi serasah akan lebih besar lagi, seperti yang dikemukakan oleh Wieder dan Wright (995); Lawrence dan Foster (2002); Lian dan Zhang (1998) dalam Triadiati et al. (2011), bahwa kebanyakan hasil penelitian pada hutan tropis menunjukkan melimpahnya serasah daun pada saat puncak musim kering. Pola musiman puncak serasah tergantung pada daun yang telah tua dan gugur. 


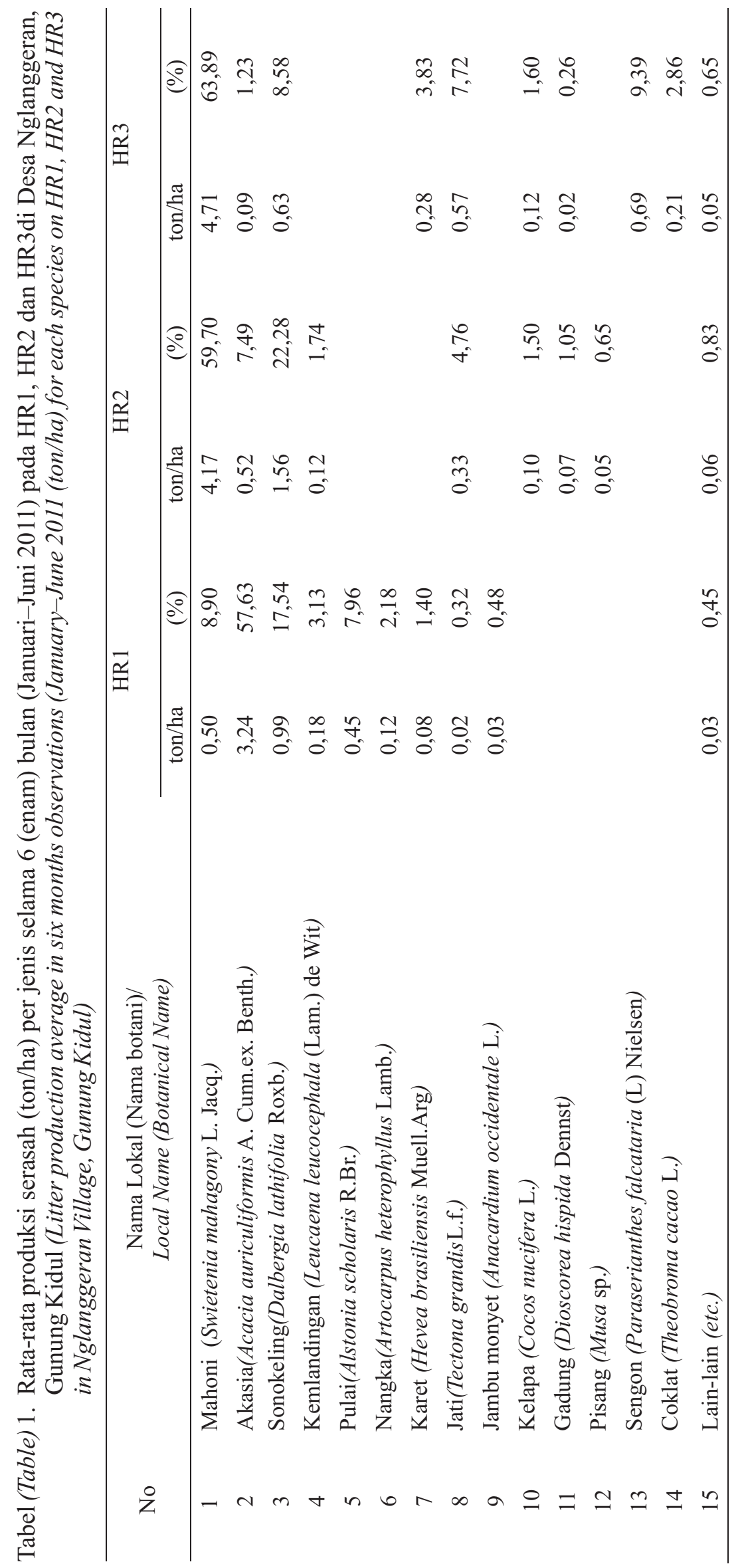


Menurut Schroth dan Sinclair (2003), jumlah produksi biomassa pohon agroforestri tergantung pada jenis spesies, jumlah pohon per hektar, umur pohon, pengelolaan tanaman dan faktor tempat tumbuh. Demikian pula yang dikemukakan Tang (2010) bahwa serasah baik produksi, variasi tahunan maupun komposisinya kemungkinan dipengaruhi oleh umur yang berhubungan dengan tahapan suksesi, komposisi jenis, struktur komunitas dan bentuk tajuk. Selanjutnya kejadian alam gangguan manusia juga dapat berkontribusi dalam meningkatkan produksi serasah dan variasi tahunan.

Produksi serasah pada pekarangan lebih rendah daripada tegalan karena berdasarkan komposisi penyusun pekarangan selain tanaman MPTS seperti melinjo, mangga, pete, nangka dan lain-lain, pada bidang olah bawah tegakan dimanfaatkan dengan tanaman semusim, sehingga kepadatan tanaman tidak didominasi oleh pepohonan.

Serasah pada masing-masing plot didominasi oleh jenis yang berbeda (Tabel 1). Pada hutan, jenis yang dominan adalah akasia $(57,63 \%)$ dan sonokeling $(17,54 \%)$, pada pekarangan didominasi oleh mahoni $(59,70 \%)$ dan sonokeling $(22,28 \%)$ dan tegalan didominasi oleh mahoni $(63,89 \%)$ dan sengon $(9,39 \%)$. Selain itu ada pula jenis-jenis lain dalam jumlah yang relatif kecil seperti pada Tabel 1. Perbedaan produksi serasah ini kemungkinan tidak disebabkan oleh kondisi tanah, karena umumnya kondisi tanahnya tidak memiliki perbedaan yang mencolok antar masingmasing plot.

Jenis serasah yang mendominasi pada ketiga plot juga merupakan jenis yang dominan dalam pertumbuhannya di lapangan. Akasia mendominasi pada HR1, dan hal ini sangat mempengaruhi ekosistem hutan sendiri karena akasia merupakan jenis yang serasahnya sulit terdekomposisi sehingga serasah akan menumpuk dan menyebabkan ketersediaan unsur hara akan terhambat. Keberadaan makro dan mikrofauna di tanah juga akan berkurang karena minimnya makanan yang tersedia dan hanya jenis-jenis tertentu yang dapat mengkonsumsi serasah akasia seperti yang dikemukakan Ganesh (2009), bahwa serasah akasia memiliki kandungan lignin dan polifenol yang tinggi, sehingga tidak disukai oleh kebanyakan cacing tanah. Tidak jauh berbeda dengan HR1, pada HR2 dan HR3 jenis yang mendominasi adalah mahoni. Serasah mahoni merupakan jenis yang juga sulit terdekomposisi. Untuk itu, dalam pengembangan hutan rakyat selanjutnya, pertimbangan pemilihan jenis dan pengaturan ruang harus menjadi salah satu syarat. Memadukan jenis yang lambat terdekomposisi dengan jenis yang cepat terdekomposisi sangat dianjurkan agar ketersediaan unsur hara dapat terjadi terus menerus sehingga kebutuhan tanaman dapat terpenuhi. Menurut Utomo (2009), pencampuran serasah berbeda jenis dan kualitas meningkatkan peluang serangan agen dekomposer terhadap serasah yang kurang berkualitas dibandingkan dengan serasah tersebut tidak dicampur dengan jenis serasah lain yang lebih berkualitas.

Berdasarkan komposisi serasah menurut bagian-bagian tanaman (Gambar 2), seluruh plot serasahnya didominasi oleh daun. Pada HR2 fraksi daun mendominasi sebesar 5,150 ton/ha atau $77,07 \%$, ranting sebesar 1,379 ton/ha $(20,63 \%)$ dan buah/bunga sebesar 0,153 ton/ha atau 2,29\% dari total produksi. Komposisi serasah yang didominasi daun sangat baik dalam mengembalikan kesuburan tanah karena lebih mudah terdekomposisi, kandungan N, P dan K pada daun juga lebih besar jika dibandingkan bagian tanaman yang lain. Menurut Bray dan Gorham (1964) dalam Agusril (1985), serasah daun lebih sering gugur dibandingkan serasah lain. Hal ini disebabkan oleh bentuk daun yang lebar, tipis yang mudah digugurkan oleh angin dan curah hujan atau dapat pula disebabkan oleh sifat fisiologi dari daun yang penting dalam proses fotosintesis untuk membuat bahan makanan.

Pada HR3, serasah didominasi oleh daun sebesar 5,218 ton/ha/6 bln, lebih tinggi dari yang ditemui pada hutan dan pekarangan, dan produksi ranting serta bunga/buah berturut-turut adalah 1,576 ton/ha $(23,02 \%)$ dan 0,052 ton/ha $(0,77 \%)$. Tingginya produksi daun pada HR3 disebabkan oleh kanopi pada HR3 didominasi oleh mahoni yang memiliki tajuk lebat yang cukup rapat dan saling bertautan. Menurut Martius, et al. (2004), produksi serasah berhubungan erat dengan penutupan kanopi yang menunjukkan struktur tegakan. HR1 didominasi oleh akasia dengan pertumbuhan yang tidak optimal sehingga potensi tegakannya rendah dan pada HR2, pola tanam tumpangsari menyebabkan luasan lahan untuk tanaman kehutanan (pohon) sebagai penghasil serasah utama berkurang menyebabkan produksi serasahnya juga menjadi lebih kecil. Komposisi jenis penyusun ini mempengaruhi komposisi serasah itu sendiri karena berhubungan dengan perbedaan tiap-tiap jenis dalam waktu meng- 
gugurkan daunnya serta kandungan nutrisi yang berbeda-beda. Hal ini dapat digunakan sebagai landasan dalam pengaturan komposisi jenis, sehingga dapat dipilih jenis-jenis yang produksi serasahnya cukup banyak tetapi juga mudah terdekomposisi sehingga dapat meningkatkan kandungan unsur hara tanah.
Berdasarkan hasil analisis kandungan $\mathrm{N}, \mathrm{P}$ dan K serasah, masing-masing plot berbeda-beda kandungannya (Gambar 3). Kandungan $\mathrm{N}$ jauh lebih tinggi jika dibandingkan $\mathrm{P}$ dan $\mathrm{K}$ pada serasah tanaman. Menurut Yar et al. (2013), daun mempunyai kandungan $\mathrm{N}$ lebih besar daripada batang karena pada akhir masa pertumbuhan,

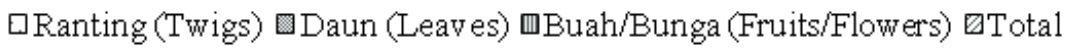
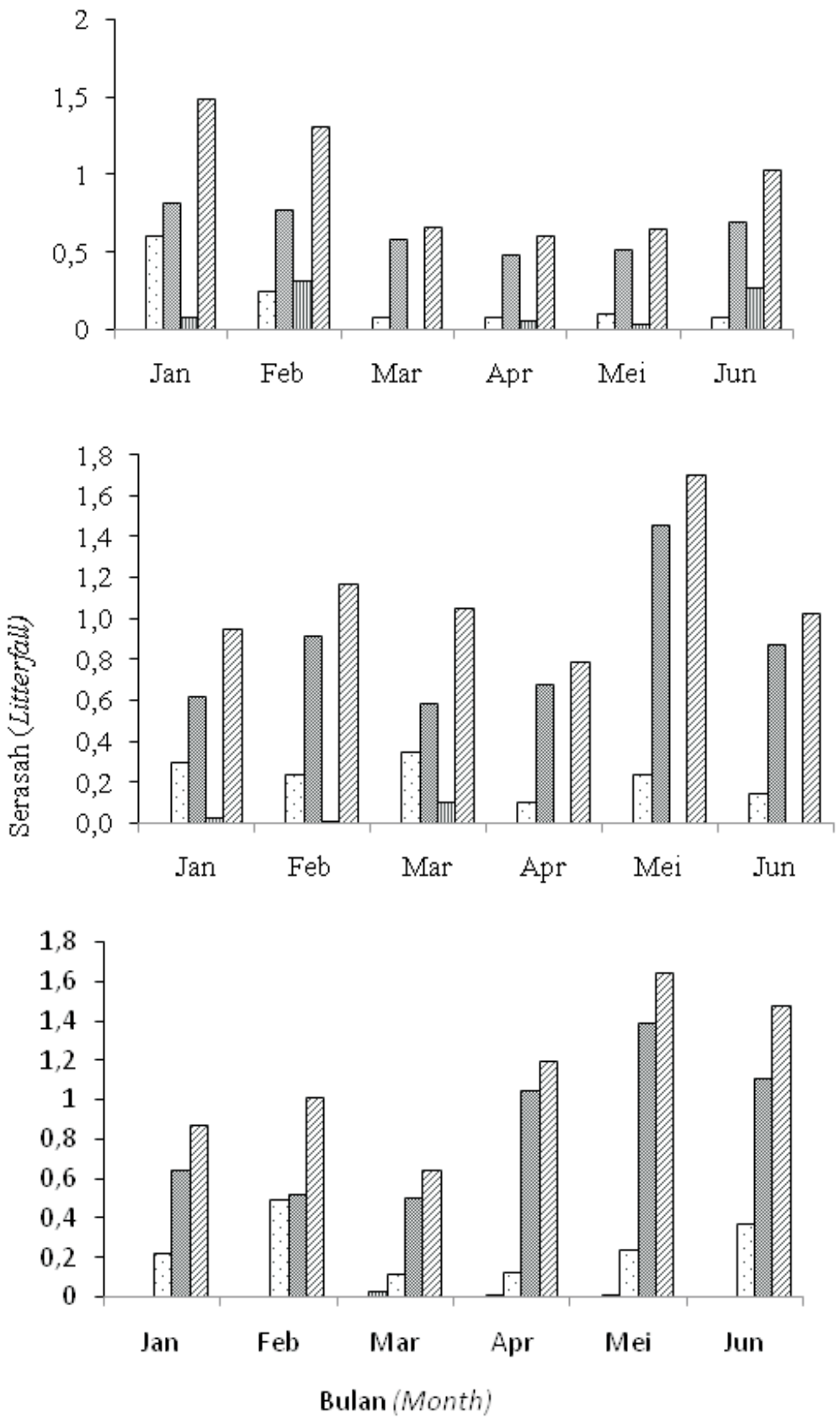

Gambar(Figure) 2. Rata-rata produksi serasah (ton/ha) selama enam bulan pada HR1 (atas), HR2 (tengah), dan HR3 (bawah) di Desa Nglanggeran, Gunung Kidul (Litter production average for six months (ton/ha) on HR1 (top), HR2 (middle) and HR3 (bottom) in Nglanggeran Village, Gunung Kidul) 


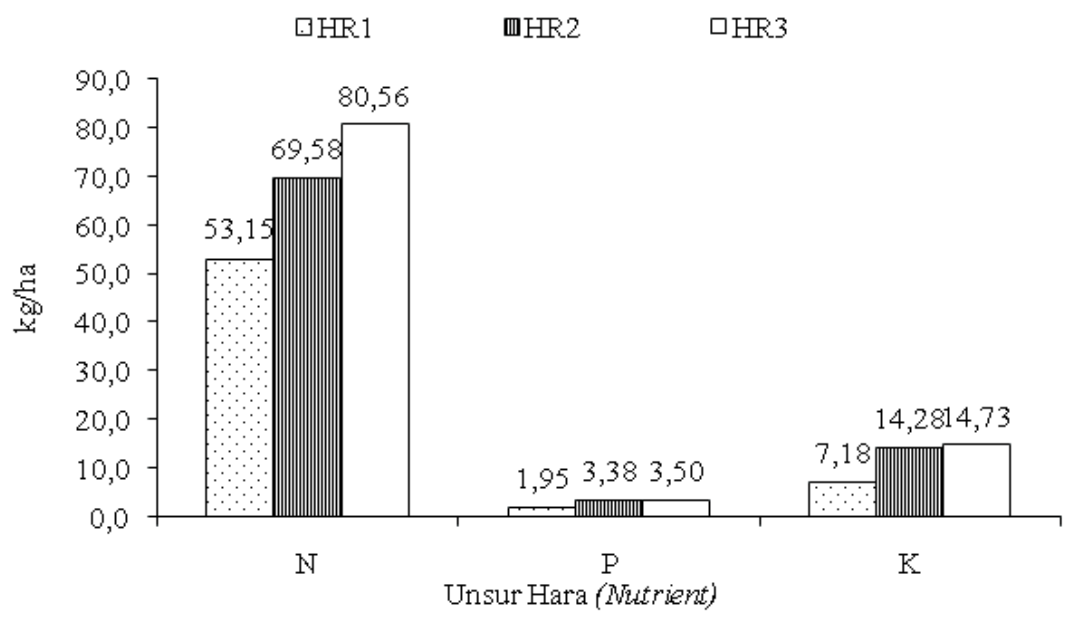

Gambar (Figure) 3. Rata-rata kandungan hara serasah (kg/ha) selama enam bulan pengamatan pada hutan rakyat di Desa Nglanggeran, Gunung Kidul (Average nutrient content in litter for six months production in communty forest of Nglanggeran Village, Gunung Kidul)

tanaman memindahkan $\mathrm{N}$ dari pucuk melalui daun.

Kandungan hara pada serasah HR3 lebih tinggi jika dibandingkan serasah HR1 dan HR2. Dengan produksi serasah sebesar 6,052 ton/ha selama 6 (enam) bulan akan menambah unsur hara ke tanah sebesar $80,56 \mathrm{~kg} / \mathrm{ha} \mathrm{N} ; 3,50 \mathrm{~kg} / \mathrm{ha}$ $\mathrm{P}$; dan $14,73 \mathrm{~kg} / \mathrm{ha} \mathrm{K}$ apabila serasah terdekomposisi seluruhnya (rasio $\mathrm{C} / \mathrm{N}$ rendah). HR1 menyumbangkan serasah lebih rendah daripada HR3 dan HR2, dari produksi serasah sebesar 4,613 ton/ha selama 6 (enam) bulan, terkandung unsur hara sebesar $53,15 \mathrm{~kg} / \mathrm{ha} \mathrm{N} ; 1,95 \mathrm{~kg} / \mathrm{ha} \mathrm{P}$ dan $7,18 \mathrm{~kg} / \mathrm{haK}$.

Konsentrasi N pada serasah HR3 cukup besar jika dibandingkan kedua plot lainnya, hal ini dimungkinkan karena adanya tanaman sengon yang menyumbang serasah sebesar 9,39\%. Sengon merupakan jenis legum yang mampu memfiksasi nitrogen. Demikian pula halnya dengan serasah akasia yang mendominasi pada HR1, akan tetapi jumlah produksi serasah pada HR3 yang cukup besar mampu meningkatkan kandungan N serasah. Menurut Palm (1995) dalam Scroth \& Sinclair (2002), konsentrasi nutrisi pada bagian yang berbeda dari biomassa terutama bergantung pada jenis spesies, tahap fenologi (misalnya menua, pembungaan), pengelolaan dan faktor tapak. Pohon yang memfiksasi nitrogen normalnya mempunyai konsentrasi nitrogen yang lebih tinggi pada biomassa daripada spesies yang tidak memfiksasi nitrogen, tetapi karakteristik ini juga sangat bervariasi antar spesies.
Konsentrasi $\mathrm{P}$ pada ketiga plot bervariasi, yang paling rendah adalah pada HR1 $(1,95 \mathrm{~kg} / \mathrm{ha})$ dan paling tinggi pada HR2 $(3,38 \mathrm{~kg} / \mathrm{ha})$. P merupakan unsur yang tingkat ketersediaannya pada tanah sangat rendah demikian pula yang dapat diserap oleh tanaman. Pada saat berada pada jarigan tanaman, $P$ sangat mudah berpindah tempat dari jaringan cabang maupun bagian tanaman lainnya (Rodriguez et al., 2011). Menurut Baker (1950) kandungan P pada serasah dipengaruhi oleh umur tanaman penghasil serasah tersebut, karena kandungan $\mathrm{P}$ akan menurun seiring dengan bertambahnya umur tanaman. Konsentrasi K pada HR3(14,73 kg/ha) lebih tinggi daripada HR2 (14,28 kg/ha) dan HR1 (7,18 kg/ha). K memiliki komposisi yang lebih kecil daripada $\mathrm{N}$ tetapi lebih besar dari $\mathrm{P}$ dan $\mathrm{K}$ relatif mobile dan siap tercuci dari daun oleh hujan (Baker, 1950).

\section{KESIMPULAN DAN SARAN}

\section{A. Kesimpulan}

1. Produksi serasah terbanyak berturut-turut adalah pada tegalan $(6,052$ ton/ha/ 6 bln $)$; pekarangan $(5,637$ ton/ha/ 6 bln $)$ dan hutan $(4,613$ ton/ha/6 bln). Daun merupakan bagian tanaman yang paling besar komposisinya dalam menyumbang serasah yaitu pada tegalan $(5,218$ ton/ha atau $76,22 \%$ total serasah), diikuti pekarangan $(5,150$ ton/ha atau $77,07 \%)$, dan terendah pada hutan $(3,816$ ton/ha atau 66,96 $\%)$. Kondisi ini menunjukkan bahwa produksi dan komposisi serasah dipengaruhi oleh struktur dan komposisi tegakan penyusunnya. 
2. Apabila seluruh serasah terdekomposisi semuanya (Rasio $\mathrm{C} / \mathrm{N}$ rendah) dan menjadi unsur hara yang tersedia bagi tanaman, maka serasah tegalan selama enam bulan akan menyumbang unsur hara ke tanah sebesar 80,56 $\mathrm{kg} / \mathrm{ha} \mathrm{N} ; 3,50 \mathrm{~kg} / \mathrm{ha} \mathrm{P}$; dan $14,73 \mathrm{~kg} / \mathrm{ha} \mathrm{K}$, lebih besar jika dibandingkan dengan pekarangan sebesar $69,58 \mathrm{~kg} / \mathrm{ha} \mathrm{N} ; 3,38 \mathrm{~kg} / \mathrm{ha} \mathrm{P}$ dan $14,28 \mathrm{~kg} / \mathrm{ha} \mathrm{K}$, dan hutan sebesar sebesar $53,15 \mathrm{~kg} / \mathrm{ha} \mathrm{N} ; 1,95 \mathrm{~kg} / \mathrm{haP}$ dan $7,18 \mathrm{~kg} / \mathrm{haK}$.

\section{B. Saran}

Kandungan unsur hara serasah ini belum mencukupi apabila akan digunakan untuk memenuhi kebutuhan pupuk pada tanaman pertanian intensif seperti jagung dan tanaman palawija lainnya, demikian pula untuk memenuhi kebutuhan hara tanaman kehutanan sehingga perlu dikombinasikan dengan jenis legum seperti sengon, kaliandra, dan lain-lain dengan struktur dan komposisi yang seimbang.

\section{DAFTAR PUSTAKA}

Agusril. (1985). Pengukuran Produktifitas Serasah pada Hutan Hujan Tropika Bekas Tebangan di Muara Tembesi Jambi. Tidak dipublikasikan. Skripsi. Fakultas Kehutanan IPB Bogor.

Anderson, J.M., \& Ingram, J.S.I. (1993). Tropical soil biology and fertility: a Handbook of methods. CAB International, Wallingford, UK.

Anonim. (2005). Monografi Dusun Nglanggeran Kulon.

Baker, F.S. (1950). Principle of Silviculture. New York: McGraw-Hill Company.

Balai Penyuluhan Pertanian Patuk. (2011). Program penyuluhan pertanian Balai Penyuluhan Pertanian Patuk. Badan Pelaksana Penyuluhan dan Ketahanan Pangan Kabupaten Gunung Kidul.

Dirjen RLPS. 2006. Data potensi hutan rakyat Indonesia. Jakarta: Dirjen RLPS Dephut.

Ganesh, P.S., Gajalaksmi, S. \& Abbasi, S.A. (2009). Vermicomposting of the leaf litter of Acacia (Acacia auriculiformis): Possible roles of reactor geometry, polyphenols, and lignin. Bioresource Technology 100: 1819-1827.

Gnankkambary Z., Bayala, J., Malmer, A., Nyberg, G., \& Hien, V. (2008). Decomposition and nutrisi release from mixed plant litters of contrasting quality in an agroforestri Parkland in the South Sudanese Zone of West Africa. Nutrient Cycle Agroecosystem Journal 82:1-13.
Indriyanto. (2009). Produksi serasah pada komunitas hutan yang dikelola petani dalam Register 19 Provinsi Lampung. Prosiding Penelitianpenelitian Agroforestri di Indonesia. Hal. 7583. Lampung: INAFE Punlisher.

Jamadi, S. (2009). Sejarah pertanian. Akses tanggal 6 Desember 2010, dari www.docstock. com.

Joe, B., Bolognesi, C., Brock, T., Capri, E., Hardy, A., Hart, A., et al. (2010). Scientific opinion: Scientific opinion on the importance of the soil litter layer in agricultural areas. Efsa Journal 8(6):1-21.

Jose, S. (2009). Agroforestry for ecosystem service and environmental benefit: An overview. Agroforestry System 76:1-10.

Martius, C., Hofer, H., Garcia M.V.B., Rombke, J., \& Hanagarth, W. (2004). Litterfall, litter stock and decomposition rates in rainforest and agroforestry sites in Central Amazonia. Nutrient Cycling in Agroecosystem 68:137154.

Murovhi, N.R., Materechera, S.A., \& Mulugeta, S.D. (2012). Sesonal changes in litterfall and its quality from three sub tropical fruit free species at Nelsprint, South Africa. Agroforestry System 86:61-71.

Nair, P.K.R., Kumar, B.M. \& Nair, V.D. (2009). Agroforestry as a strategy for carbon sequestration. Journal of Plant Nutrition and Soil Science 172:10-23.

Rahajoe, J.S., \& Alhamd, L. (2013). Biomassa guguran serasah dan variasi musiman di hutan dataran rendah Gunung Gede Pangrango. Jurnal Biologi Indonesia Vol. 9 No. 1.

Rodriguez, H.G., Gomez, T.G.D., Silva, I.C., Meza, M.V. G., Lozano, R.G.R., Moreno, M.P., et al. (2011). Litterfall deposition and leaf litter nutrient return in different location at Northeastern Mexico. Plant Ecology 212: 17471757.

Sangha, K., Jolata, K., R.K., \& Midmore, D.J. (2006). Litter production, decomposition, and nutrient release in cleared and uncleared pastures system of Central Queensland Australia. Journal of Tropical Ecology 22:177-189.

Schmidt, F.H., \& Ferguson, J.H.A. (1951). Rainfall based on wet and dry period ratios for Indonesia with Western New Guinea.Verhand. 42. Jakarta: Djawatan Meteorologi dan Geofisika. Kementerian Perhubungan.

Scroth, G. \& Sinclair, F.L. 2002. Trees, crops and soil fertility: Concepts and research methods. Oxon, UK: Cabi Publishing. 
Siarudin, M., \& Rahman, E. (2010). Biomassa lantai hutan dan jatuhan serasah di Kawasan Mangrove Blanakan, Subang, Jawa Barat. Jurnal Penelitian Hutan dan Konservasi Alam Vol V(4): 329-335.

Sunu, P., \& Wartoyo. (2006). Buku ajar hortikultura. Surakarta: Universitas Sebelas Maret.

Tang, J.W., Cao, M., Zhang, J.H., \& Li, M.H. (2010). Litterfall production, decomposition and nutrient use efficiency varies with tropical forest types in Xishuang banna, SW China: a 10-year Study. Plant Soil 335:271-288.

Triadiati, Tjitrosoemito, S., Guhardja, Sudarsono, E., Qayim, I., \& Leuschner, C. 2011. Litterfall production and leaf-litter decomposition at natural forest and cacao agroforestry in Central Sulawesi, Indonesia. Asian Journal of Biology Sciences 4 (3):221-234.

Tripathi, O.P., Pandey, H.N., \& Tripathi, R.S. 2009. Litter production, decomposition and phsico- chemical properties of soil in 3 developed agroforestry system of Meghalaya, Northeast India. African Journal of Plant Science Vol. 3 (8):160-167.

Utomo, S. 2009. Laju dekomposisi serasah johar (Cassia siamea Lamk.) dan kedelai (Glicine max (L.) Merril) pada berbagai bentuk pemanfaatan lahan. Tidak dipublikasikan. Skripsi Fakultas Kehutanan Universitas Gajah Mada. Yogyakarta.

Widyastuti, S.M., Sumardi, \& Nurjanto, H.H. (1998). Pelepasan unsur hara dalam proses dekomposisi serasah sebagai petunjuk aktivitas mikroorganisme di bawah tegakan Acacia mangium. Buletin Kehutanan No. 35: 11-19.

Yar, S., Akbarlou, M., Jafari, I. (2013). Evaluation litter quality of three plant species and their effect on soil fertility in Miankaleh Biosphere Reserve North of Iran. International Journal of Agriculture: Reserach and Review Vol. 3(2): 393-400. 
Lampiran (Appendix). Jumlah tanaman dan indeks nilai penting pada HR1, HR2 dan HR3 (Luas plot 1200 $\left.\mathrm{m}^{2}\right)$ (Plant number and important value index on HR1, HR2 and HR 3 )

A. HR1

\begin{tabular}{|c|c|c|c|c|c|c|c|}
\hline \multirow[t]{2}{*}{ No. } & \multirow{2}{*}{$\begin{array}{l}\text { Nama lokal } \\
\text { (Local name) }\end{array}$} & \multirow{2}{*}{$\begin{array}{c}\text { Nama botani } \\
\text { (Botanical name) }\end{array}$} & \multirow{2}{*}{$\begin{array}{c}\text { Jumlah } \\
\text { tanaman } \\
\text { (Plant } \\
\text { number) }\end{array}$} & \multicolumn{4}{|c|}{$\begin{array}{l}\text { INP Pert tingkat pertumbuhan } \\
\text { (IVI per growth level) }\end{array}$} \\
\hline & & & & $\begin{array}{c}\text { Semai } \\
\text { (Seedling) } \\
\end{array}$ & $\begin{array}{l}\text { Sapihan } \\
\text { (Sapling) }\end{array}$ & $\begin{array}{l}\text { Tiang } \\
\text { (Pole) }\end{array}$ & $\begin{array}{l}\text { Pohon } \\
\text { (Tree) }\end{array}$ \\
\hline 1 & Sonokeling & Dalbergia lathifolia & 73 & 93,92 & & 34,96 & 77,71 \\
\hline 2 & Akasia & Acacia auriculiformis & 119 & 59,12 & 154,48 & 196,28 & 201,07 \\
\hline 3 & Mete & $\begin{array}{l}\text { Anacardium } \\
\text { occidentale }\end{array}$ & 6 & 16,55 & & 34,84 & \\
\hline 4 & Karet & Hevea brasiliensis & 7 & 16,55 & 9,83 & & 21,23 \\
\hline 5 & Pulai & Alstonia scholaris & 8 & 13,85 & 36,36 & 11,20 & \\
\hline 6 & Duwet & Syzygium cumini & 2 & & 18,68 & 11,52 & \\
\hline 7 & Cendana & Santalum album & 1 & & 9,63 & & \\
\hline 8 & Mahoni & Swietenia mahagoni & 7 & & 50,79 & & \\
\hline 9 & Nangka & Artocarpus integra & 1 & & & 11,20 & \\
\hline
\end{tabular}

B. HR2

\begin{tabular}{|c|c|c|c|c|c|c|c|}
\hline \multirow[b]{2}{*}{ No } & \multirow{2}{*}{$\begin{array}{l}\text { Nama } \\
\text { Lokal } \\
\text { (Local } \\
\text { name) }\end{array}$} & \multirow{2}{*}{$\begin{array}{l}\text { Nama botani } \\
\text { (Botanical name) }\end{array}$} & \multirow{2}{*}{$\begin{array}{c}\text { Jumlah } \\
\text { tanaman } \\
\text { (Plant } \\
\text { number) }\end{array}$} & \multicolumn{4}{|c|}{$\begin{array}{l}\text { INP Pert tingkat pertumbuhan } \\
\text { (IVI per growth level) }\end{array}$} \\
\hline & & & & $\begin{array}{c}\text { Semai } \\
\text { (Seedling) }\end{array}$ & $\begin{array}{l}\text { Sapihan } \\
\text { (Sapling) }\end{array}$ & $\begin{array}{l}\text { Tiang } \\
\text { (Pole) }\end{array}$ & $\begin{array}{l}\text { Pohon } \\
\text { (Tree) }\end{array}$ \\
\hline 1 & Coklat & Theobroma cacao & 1 & 7,13 & & & \\
\hline 2 & Pisang & Musa paradisiaca & 2 & 8,00 & & & \\
\hline 3 & Melinjo & Gnetum gnemom & 4 & & 13,43 & & 20,16 \\
\hline 4 & Mangga & Mangifera indica & 2 & & & 13,80 & 5,20 \\
\hline 5 & Pete & Parkia speciosa & 3 & & & 16,35 & 11,89 \\
\hline 6 & Kelapa & Cocos nucifera & 4 & & & & 20,16 \\
\hline 7 & Mente & Anacardium occidentale & 1 & & & & 5,64 \\
\hline 8 & Jengkol & $\begin{array}{l}\text { Archidendron } \\
\text { pauciflorum }\end{array}$ & 2 & & & & 10,41 \\
\hline 9 & Nangka & Artocarpus integra & 2 & & & & 11,27 \\
\hline 10 & Mahoni & Swietenia mahagony & 174 & 87,61 & 257,72 & 194,96 & 145,22 \\
\hline 11 & Sonokeling & Dalbergia lathifolia & 74 & 78,62 & 15,41 & 42,07 & 51,97 \\
\hline 12 & Jati & Tectona grandis & 4 & & 13,43 & 15,23 & 7,27 \\
\hline 13 & Akasia & Acacia auriculiformis & 3 & & & 17,59 & 10,82 \\
\hline
\end{tabular}


C. HR3

\begin{tabular}{|c|c|c|c|c|c|c|c|}
\hline \multirow[t]{2}{*}{ No. } & \multirow{2}{*}{$\begin{array}{c}\text { Nama lokal } \\
\text { (Local } \\
\text { name) }\end{array}$} & \multirow{2}{*}{$\begin{array}{c}\text { Nama botani } \\
\text { (Botanical name) }\end{array}$} & \multirow{2}{*}{$\begin{array}{c}\text { Jumlah } \\
\text { tanaman } \\
\text { (Plant } \\
\text { number) }\end{array}$} & \multicolumn{4}{|c|}{$\begin{array}{l}\text { INP Per tingkat pertumbuhan } \\
\text { (IVI per growth level) }\end{array}$} \\
\hline & & & & $\begin{array}{c}\text { Semai } \\
\text { (Seedling) }\end{array}$ & $\begin{array}{l}\text { Sapihan } \\
\text { (Sapling) }\end{array}$ & $\begin{array}{l}\text { Tiang } \\
\text { (Pole) }\end{array}$ & $\begin{array}{l}\text { Pohon } \\
\text { (Tree) }\end{array}$ \\
\hline 1 & Duwet & Syzygium cumini & 2 & 9,44 & & & \\
\hline 2 & Melinjo & Gnetum gnemon & 1 & & 17,52 & & \\
\hline 3 & Cengkeh & Syzygium aromaticum & 1 & & & 9,65 & \\
\hline 4 & Mangga & Mangifera indica & 2 & & & 11,07 & 4,75 \\
\hline 5 & Pete & Parkia speciosa & 2 & & & 11,34 & 4,42 \\
\hline 6 & Kelapa & Cocos nucifera & 10 & & & & 25,56 \\
\hline 7 & Mahoni & Swietenia mahagony & 179 & 102,50 & 211,70 & 235,78 & 115,50 \\
\hline 8 & Sonokeling & Dalbergia lathifolia & 30 & 80,00 & 51,72 & & 15,28 \\
\hline 9 & Jati & Tectona grandis & 16 & 8,06 & 19,07 & 20,24 & 34,43 \\
\hline 10 & Sengon & $\begin{array}{l}\text { Paraserianthes } \\
\text { falcataria }\end{array}$ & 16 & & & 11,91 & 32,84 \\
\hline 11 & Akasia & Acacia auriculiformis & 2 & & & & 5,88 \\
\hline
\end{tabular}

